\title{
The 2015 Kogi State Gubernatorial Election and the Crisis of Political Mandate: The Failure of Party Politics?
}

\author{
S. M. Omodia PhD. \\ Head, Departmenmt Of Political Science \\ Kogi State University, Anyigba, \\ Kogi State, Nigeria
}

\begin{abstract}
This paper discusses the crisis of political mandate in the 2015 kogi state gubernatorial election with specific focus on the All Progressive Congress (APC). The paper using Almond and Verba's conception of political culture as a framework of analysis, unfolds the poor aggregative capability of the Nigeria party system as well as the restrictive participatory political culture in the process of elite recruitment. The argument of the paper is that the current crisis of political mandate in kogi state which is associated with 2015 gubernatorial election is a function of the failure of the Nigerian party system to provide through an encompassing participatory process, shared aspiration and party ideals of political representation as a tool of crisis management at the intraparty level. The result has been party indiscipline, disloyalty and the externalization of conflicts through the over-independence on judicial interpretations and pronouncements by the courts at the expense of the electoral process. In conclusion ,the paper accentuate that if the present democratic experiment of the Nigerian fourth republic is to stand the test time, the process must be built on a functional aggregative capability of political parties that is anchored on a participant political culture.
\end{abstract}

Keywords: Electoral process, Interest aggregation, Party Politics, Political Culture, Political Mandate, Political Parties

\section{INTRODUCTION}

The November 21, 2015 kogi state gubernatorial election could be viewed as a process that was quite indispensable to the future of democratic stability in Nigeria. This is based on the conception that it was the first to be conducted by the newly elected Buhari Administration at the center and coupled with the fact that it was the very first to be conducted by the Prof Yakubu Mahmoud led Independence National Electoral Commission (INEC). Thus, the process was viewed as an electoral process that could aid in defining the electoral focus of the Nigerian state either positively or negatively.

Positively in the sence that it could provide an interpretation of what to expect of the Buhari led administration in terms of consolidating on electoral successes recorded by the immediate past administration of Goodluck Jonathan. Negatively on the other hand, in determining the democratic credentials of a retired military general turned politician in order to observe if the electoral gains achieved in the past would be eroded by the militarization and dictatorial attributes associated with military officers

However, crucial to the electoral process are political parties who are expected to provide candidates for election, as a matter of fact, political parties does not only provide avenue for political contestation, but also serve as the institution for synthesizing interests for the purpose of a unified party position which members are not only expected to support but also 
protect, this is coupled with the function of providing political education, mobilizing and enhanced political participation by members (Almond et al, 2000; Bello,2008; Omodia,2010; Omodia, 2012)

Conversely, the crisis associated with the emergence of a new party candidate for the All Progressive Congress (APC) for the conclusion of the governorship election in December 5, 2015 after the demise of Prince Abubakar Audu the governorship candidate for the November 21 election could be said to be an indication of the failure of the Nigerian political parties as political institutions for bringing together people of like minds who possesses shared interest of taking over government for the purpose of the realization of party ideas rather than the pursuance of selfish and factious interest. The scenario could also be indicative that political parties in the Nigerian state in the present democratic experiment are weak and fragile political institutions which need to be strengthened through years of democratic practice.

Although, this paper is specifically focused on the crises of political mandate within a political party (APC), the perspective of this paper is that the failure of political parties or otherwise could be generalized based on the attribute and manifestation of political parties in Nigeria which has witnessed defection of members as a result of dissatisfaction with party primariesdefections to political parties for the purpose of emerging as party candidates without consideration for party ideas, orientation and shared party objectives (Kew and Lewis, 2007; Omodia, 2012)

As a result, the focus of this paper is to unfold the crisis of political mandate in the just concluded 2015 kogi state gubernatorial election in Nigeria by situating it within the context of party politics. To be able to achieve this purpose in addition to the introduction the paper is sectionalized into: frame work of analysis, political mandate in APC before the election, the crisis of political mandate and the 2015 elections, APC and the management of the crisis, as well as, concluding remarks,

\section{THEORETICAL FRAMEWORK}

Central to party politics is political culture; an entrenched culture to a great extent influences the process of elite recruitment and political socialization of members by political parties. This is quite indispensable if political culture is viewed as an enduring political practice by a group of people, citizens of a nation, which has come to stay as a way of organizing political life of the people.

This however does not mean that political behavior is static, but changes are shared by the people as necessary and thus accepted as improvement to the political organization of the people. As a result, there are typologies of political culture, and as regard the subject of political culture, the conception and theory of Almond and Verba (1963) comes to mind.

The classification of political culture according to Almond and Verba (1963) are: parochial political culture, subject political culture and participant political culture.

Parochial political culture- this manifestation of political culture relates to a system where governance is exclusive of the greater number of the people as a result of poor political awareness which does not enable them to actively participate in the governmental process. Thus, when this is situated within partyism and political mandate, one could convincingly say 
that partyism is largely elitist in nature in that the political elites determined and control the political process of acquiring political mandate is largely restrictive

Subject political culture: the belief system expressed in the subject political culture shows a divide between the masses who are not political actors and the political elites who are political actors. In other words, even though the masses are aware of the existence of government and its machinery, the active participation in the governmental process is seen as exclusive to the political actors. This scenario could be said to be synonymous with the platonial conception of state stratification were the right to governance belongs to the philosophical king (Sabine and Thorson, 1973; Mukherjee and Ramaswamy, 2007; Omodia, 2011a). The implication of the above especially as regard political mandate in kogi state is that political culture is expressed as the right of a particular ethnic group (The Igalas) to dominate governance and that the success of political parties at the polls is a function of where the candidates of the leading political parties come from.

The above scenario may not be too divorced from the crisis associated with the emergence of Yahaya Bello from an ethnic minority in the state as the candidate of the APC after the demise of Prince Abubakar Audu, from an ethnic majority who has dominated the highest political office in the state in democratic dispensations.

Participant political culture- By participant political culture unlike the parochial and subject culture, the conception is that the citizen/masses are actively involved in the political process. In emerging democracies such as Nigeria active participation in the political process is expected to be a function of political education, mobilization, interest aggregation, elite recruitment among others (Omodia, 2011b)

As regard elite recruitment and emergence of party candidate, it shows that a people centered political party is supposed to provide a built in mechanism within the party structure that enables for the active participation of it members in the process for determining party representatives and candidates. On observational note intra-party democracy as regard the emergence of party candidates is often associated with political crisis that tend to threaten the survival of democracy in the Nigeria fourth republic. Thus, the import of this paper is to look at political parties and the crisis of political mandate in the 2015 kogi state gubernatorial election in Nigeria with specific focus on the APC.

\section{Political Mandate in APC before the Election}

The APC is a political party formed by the merger of the major opposition party to the People Democratic Party (PDP) led administration at the center. It is a merger of the Action Congress of Nigeria (ACN) prominently visible in the South-West of Nigeria, the Congress for Progressive Change (CPC) conspicuously visible in the North-West and North-Central, the All Nigeria Progressive party (ANPP) visible in the North-East and a section of the All Progressive Grand Alliance (APGA) which is prominently visible in the South-East. When the APC was formed and registered in 2013, political actors especially the party in government at the center felt that the demise of the party was just a matter of time based on what could be referred to as ideological incompatibility or divergence in the personal orientation and approach of key political actors of the party to issues of governance (Terwase, Abdul-Talib and Zengeni, 2015)

The APC no doubt was aware of the pessimistic conception of some Nigerians and as matter of fact, the key actors in PDP to the survival of the party. Thus, the strategy of the party was to ensure free and fair process in the emergence of candidates during party primaries. As matter of fact, Before the Presidential party primaries the contesting candidates were made to reach 
an agreement of ensuring that the party remains united through non defection of aspirants who did not emerge as the party flag bearer. In the case of kogi state, 20 aspirants contested for the candidacy of the party with Prince Abubakar Audu emerging as the winner with a delegate vote of 1109 , Yahaya Bello came second with a vote of 703, while the remaining 1,119 votes were shared among the other eighteen (18) aspirants (Oyewole, Agbo and Ojotule, 2015)

However, it is important accentuate that high level interest of aspiration for the candidacy of the APC could be attributed to: (i) the poor level of performance by the party in government, the PDP led Captain Ichalla Idris Wada as well as the crisis associated with his emergence as the party candidate in 2011 which led to the defection of some key members of the party to the then ACN (Omodia, 2012) (ii) the fact the party (APC) just took over the mantle of leadership at the center from the PDP and the expectations of aspirant that they stand a chance of winning the gubernatorial election if they could emerge as candidate as a result of the envisaged support of the party at the center

Conversely, It is important to note that typical of Nigeria and the manifestation of party politics in the Nigerian state, one could say that the high number of aspiration for the candidacy of the APC in kogi state, just like what was obtainable in the PDP in the past may likely lead to dissatisfaction expressed by some contestant in the emergence of party candidate. This no doubt may either lead to defection to other parties or a situation where the aggrieved persons stay in the party and work for the interest of other parties or remain uncommitted to the success of his party at the polls.

Although the emergence of Prince Abubakar Audu as the party flag bearer of APC, no doubt followed a process that could be classified as free and fair; the inability of the party to however fully integrate the contestants to be committed to the goal of the party through active involvement in political campaigns led to claims of the supporters of Prince Abubakar Audu that some key members of the party especially those that contested against him worked for the party in government (PDP) in the state during the November 21 gubernatorial election (Okene, 2015)

\section{The Crisis of Political Mandate and the 2015 Election.}

The November 21 gubernatorial election was seen as a major political contest between Prince Abubakar Audu, the candidate of APC and the incumbent Governor, the candidate of the Peoples Democratic Party who was seeking a second term in office out of 22 number of candidates representing 22 political parties. It is also important to state that as part of the requirement for standing for election of thes magnitude is the need for the candidates to choose their running mate who is to serve as Deputy Governor if the party is voted into office. Thus, party tickets are regarded as joint ticket which encompasses the governorship candidate and the candidate for the deputy governor. it is also important to state that, in the process of vote cast, the names of the candidates does not appear on the ballot papers, but what appears is the name of the party and the party logo.

As regard the election which was conducted by the INEC as required by law, on the 22nd of November 2015, the state Returning Office announced that the APC got 240,867 votes while the PDP got 199,514 votes (Ndujihe et.al, 2015). However the election was declared inconclusive. The argument for declaring the November 21 election inconclusive by INEC was that the gap between APC who was the leading party the election and the closet party to the APC, the PDP was not more than the cancelled votes and that it was wrong to declare APC the 
winner since the PDP still stand a mathematical chance of winning. Considering that elections were cancelled on the ground of irregularities in 91 polling units totaling 49,953. Thus INEC opted for a supplementary election in the affected polling units in order to declare the winner of the election (Azania, 2015).

The decision of INEC was seen as controversial not only by a section APC but also by the PDP (Azania, 2015; Aziken et.al, 2015a).The crisis was heightened by the announcement of the demise of the candidate of the APC, Prince Abubakr Audu. This scenario no doubt threw up the crisis of political mandate of who becomes the candidate of the party for the supplementary election which was later scheduled to hold on December 5, 2015.

With the demise of Prince Abubakar Audu the candidate of the APC for the November 212015 gubernatorial election and the declaration of the election as inconclusive, the crisis of political mandate was based on three major political interpretations. two of those interpretations were associated with the APC while one came from the PDP. From the APC, the first interpretation is that INEC decision of declaring the election inconclusive was misleading in that APC should have been declared the winner because franchise in the election was defined by acquisition and possession of the Permanent Voters Card (PVC) by the electorate and not by registered voting population. On the strength of the PVC, only 25,000 out of the 49,953 registered voters were qualified to vote and since the gap between the APC and PDP in the election was more than 25,000, then the APC should have been declared winner (Azania, 2015). The implication of this is that with the demise of Prince Abubakar Audu, his running mate Honorable James Faleke should be declared as Governor-Elect.

The second interpretation also by a section of APC is that with the election declared inconclusive, the vacant position should be filled from among those who contested the party primaries through which Abubakar Audu emerged (Azania, 2015) The third as earlier stated is by the PDP, the party was of the conception that there should be a distinction between the candidate and the party and with the demise of the candidate, then the candidate of the PDP should be declared winner (Aziken et.al 2015b)

However, the APC decided to adopt the second interpretation and the candidate that come second to Abubakar Audu in the party primaries Alh. Yahaya Bello was picked as the candidate of the party for the December 5, supplementary election which he eventually won with 6,885 votes compared to the PDP votes of 5, 363 and was eventually sworn in as the Governor on January 27, 2016, haven been declared the overall winner by the Returning Officer, with a total vote of 247,752 as against the PDP 204,877 out of 494,723 total vote cast (Ogunwale, 2015)

The implication is that the running mate of Abubakar Audu, Hon James Faleke did not only publicly reject the candidature of Alh. Yahaya Bello and refused to be his running mate but also went to court to seek judicial interpretation, just like the PDP (Aziken et.al, 2015c).This scenario of sharp divide especially in the APC in kogi state brings to the fore the role of the party in the management of the crisis. That is, what should have been done by the party especially in bringing about a functional aggregation of interests for the purpose of having a united front?

\section{APC and the Management of the Crisis}

Political parties are political institution consisting of people of shared interest who are functionally organized to take over the machinery of government. This shows that political parties are so central to political representation in a democracy not only because it provide the 
shade for political representation, and participation but also because it performs of key functions of aggregating the interest of members for the purpose of keeping a united front. So, it is not uncommon to have divergent interests being pursued by members of the same political party especially as regard aspiration for political power, but political parties must be functionally organized in such a way that interest are aggregated through a well-defined process of intra party conflict management.

In the case of the APC and the crisis associated with political mandate in the 2015 gubernatorial election, with 20 contestants in the party primaries and with the Nigerian experience of likely party defection, disloyalty, indifference that always accompany the outcome of such exercise the party should have put in motion the mechanism for re-integrating the contestants to be actively involved in the process of achieving the goals of the party in kogi state. This functional process of interest's re-integration would have inculcated the needs for the submissiveness of individual interest to the party interest with the belief that personal interest could best be achieved under an encompassing party interest rather than a restrictive one. This no doubt would have snow ball into an enhanced political participation on the part of the political actors within the party and the crisis associated with the demise of Prince Abubakar Audu would have been better handled through a more consultative approach that would have made the key actors in the party to manifest party position in their actions.

Conversely, typical of Nigerian political parties, the APC could not effectively provide functional management of the crisis this led to accusations and counter accusations within the party, one of such accusations is that Alh. Yahaya Bello was not committed to the goal of the party after the party primaries. Some even claimed that he worked for the PDP during the November 21, 2015 gubernatorial election (Aziken et.al, 2015c).

Although the choice of Yahaya Bello as the candidate for the December 5, 2015 supplementary elections by the APC. Seems to have been guided by the River State scenario where Rotimi Amaechi through judicial pronouncement was sworn in as Governor without participating in the gubernatorial election (Isa and Zakari, 2008), however the aggregating mechanism of the party is one that negates participant political culture considering the actions of political actors. It is also important to accentuate that the spate of judicial pronouncement that nullifies the outcome of the electoral process to a great extent contributes to the fragility of the democratic process and the present crisis of political mandate associated with 2015 gubernatorial election in kogi state seem to be heading the way of judicial pronouncement at the expense of aggregative capability of political parties considering the fact that the actor have approached the court for judicial interpretation.

\section{CONCLUSION}

It therefore shows that if the present democratic experiment is to survive over time the aggregative function of political parties must be anchored on a participant political culture. The unfolding scenario in the APC associated with 2015 gubernatorial election is indicative of the failure of the Nigerian party system not only in the aspect of aggregative function but also in the aspects of political socialization and elite recruitment.

In other words, participant political culture of the people is one which must be driven by the electoral process through participatory party politics rather than over dependence on electoral tribunal and courts for deciding electoral conflicts. The conception here is that intra-party 
conflict could best be managed when political parties are so participatory that party candidates are seen as representing the shared aspirations of the party they represent

\section{Reference}

Almond, G.A. and Verba, S. (1963) The Civic Culture. Princeton: Princeton University Press

Almond, G.A. et.al (2000) Comparative Politics Today: A World View. India: Person Education Limited

Azania, J. (2015: December 6) APC's Bello takes clear lead. The Nation Newspapers P.7.

Aziken, E. et al (2015a: November 24) Audu Remains APC's Candidate.... Vanguard Newspapers P.1-5

Aziken, E. et al (2015b: November 26) Kogi polls: PDP weighs options to outst APC. Vanguard Newspapers P.1-5

Aziken, E. (2015c: December 1) Violence and APC shuns Faleke, picks Bello. Vanguard Newspapers P.1-5

Bello, K. (2008) Ideological Bankruptcy in the Practice of Nigeria: Genesis, Magnitude and Consequences. Keffi: AMD Design and communication

Isah Y.I. and Zakari, M.Y. (2008) The courts and the management of elections in Nigeria In: S.M omodia (Ed.) Managing Elections in Nigeria (PP. 112-125) Keffi: Onaivi Printing and Publishing

Kew, D. and Lewis, P. (2007) the making of modern Nigeria state In: M. Kesselman, J. Krieger and W.A. Joseph (Eds.) Introduction to Comparative Politics: Political Challenges and Changing Agendas (PP. 364-410) USA: Cengage Learning

Mukherjee, S. and Ramaswamy, S.A. (1999) A Hitory of Political Thought. India: Prentice-Hall

Ndujihe, C. et.al (2015: November 25) Kogi: Constitutional crises looms: Vanguard Newspapers P.5

Ogunwale, G. (2015: December 7) Battles shifts to court as Bello is declared governor-elect. The Nation Newspapers. P.6-8

Okene, M.U. (2015 November 8-14) APC stalwart sues for unity among party stakeholders. The Graphic Newspapers P.8

Omodia, S.M. (2010) Political parties and party politics in the Nigerian fourth republic. Trakia Journal of Science $8(3): 65-69$

Omodia, S.M. (2011a) The utility of the concept philosopher king in the Nigerian body- politics of the 21st century. International Journal of Humanities 9 (4):75-78

Omodia, S.M. (2011b) Sustaining democracy through functional political culture in the Nigerian fourth republic. Trakia Journal of sciences 9(4):75-78

Omodia, S.M. (2012) Political parties and the challenge of free and fair elections in Nigeria: a focus on kogi state gubernatorial election. European Scientific Journal 8(3): 189-199

Oyewole, J., Agbo E. and Ojotule, R. (2015: September 2) Audu waits for Wada/Echocho others. The Graphic Newspapers P.1-4

Sabine, G.H and Thorson, T.I. (1973) A History of Political Thought. New Delhi: Oxford and IBH Publishing Company

Terwase, I.T., Abdul-Talib, A.N. and Zengeni, K.T. (2015) Conflict resolution: the truncated zoning arrangement and the Buhari's Political tsunami in Nigeria. Journal of Government and Politics 6(2):248-259 